\title{
La fuerza de la ley y el asilo de la costumbre. Un proceso por fraudes y abusos en la Real Casa de Moneda de México
}

\author{
por \\ Felipe Castro Gutiérrez ${ }^{1}$ \\ Instituto de Investigaciones Históricas, Universidad Nacional Autónoma de México
}

\begin{abstract}
El artículo tiene como asunto una acusación de fraude iniciada en 1729 en contra de los oficiales de la Real Casa de Moneda de México y los mayores comerciantes de plata del virreinato, cuyo desarrollo se prolongó más de diez años y provocó una grave crisis en la mayor ceca del Imperio. Los sucesos permiten conocer situaciones institucionales y procesos industriales que normalmente no son mencionados en la documentación, comprender el papel dominante que habían llegado a tener los mercaderes, así como comentar el sentido del proceso judicial $y$ de las reformas implantadas por la Corona en las relaciones con sus súbditos indianos.

Palabras ClaVe: casas de moneda; costumbre y justicia; política monetaria; reformas borbónicas.

Cómo citar este artículo / Citation: Castro Gutiérrez, Felipe, "La fuerza de la ley y el asilo de la costumbre. Un proceso por fraudes y abusos en la Real Casa de Moneda de México", Revista de Indias, LXXVII/271 (Madrid, 2017): 759-790. doi:10.3989/revindias. 2017.022
\end{abstract}

\section{INTRODUCCIÓN}

El 7 de febrero de 1728 el virrey marqués de Casafuerte inició una inspección de la Real Casa de Moneda de la ciudad de México que pronto se transformó en una causa criminal que se prolongó más de una década. Los acusados no fueron solamente algunos personajes menores, sino también otros que tenían amplias influencias familiares y de negocios. El juez incluso levantó cargos contra los «banqueros» de plata más poderosos del virreinato,

\footnotetext{
1 fcastro@unam.mx, ORCID iD: http://orcid.org/0000-0001-9486-4579.
} 
cuyas operaciones eran esenciales para el sostén de la minería, el comercio de los metales preciosos y la recaudación de los correspondientes impuestos. Estos sucesos son del mayor interés por varias razones. Por un lado, permiten acceder a aspectos que normalmente no eran comentados en el funcionamiento cotidiano de la más antigua casa de moneda indiana ${ }^{2}$. Asimismo, la resolución final proporciona un buen ejemplo de la lógica y el sentido del proceso judicial de aquel entonces, y permite algunas consideraciones sobre las relaciones entre la monarquía y sus súbditos indianos.

El tema ha atraído alguna atención historiográfica. Laura Pérez Rosales analizó el papel en el caso de Francisco de Fagoaga, uno de los grandes mercaderes de plata, comentó los argumentos de su defensa (que giraron tanto sobre los aspectos propiamente jurídicos como sobre la necesidad económica de un mayor margen de ganancia en la comercialización y amonedación del metal precioso), así como las repercusiones sobre su empresa familiar. La autora concluyó correctamente que el proceso fue parte de una reforma de las prácticas gubernamentales tanto en España como en sus posesiones americanas ${ }^{3}$.

Debe mencionarse igualmente a Carlos Lazo García, quien se dedicó a los sucesos paralelos ocurridos en la ceca limeña, lo cual permite válidas comparaciones con el caso novohispano tanto en el carácter de la acusación como en la defensa de los implicados; asimismo, este autor estableció acertadamente que el problema de fondo era el de la insuficiente rentabilidad de la acuñación de la plata ${ }^{4}$.

En un trabajo previo me ocupé brevemente del tema en cuanto proporcionaba datos de interés para la historia social de la ceca mexicana ${ }^{5}$. El presente artículo se adentra en estos relevantes sucesos por su propia importancia, procediendo a reconstruirlos y comentarlos con el necesario detalle, además de considerar la narrativa implícita en las argumentaciones de la fiscalía y la defensa. Para estos fines, además de los miles de fojas de la causa, contamos ahora con los alegatos presentados ante los tribunales, que fueron impresos como se hacía con las «causas célebres» ${ }^{6}$. El conjunto, además de voluminoso, tiene un carácter muy técnico del punto de vista contable, industrial y

2 Sobre los orígenes y desarrollo temprano de la ceca mexicana, véanse González Gutiérrez, 1997 y Céspedes del Castillo, 1996. En cuanto al contexto institucional de la época, consúltese Soria Murillo, 1994 y Bertrand, 1999: 345-350.

3 Pérez Rosales, 2003: 25-30.

4 Lazo García, 2006.

5 Castro Gutiérrez, 2012: 85-89

6 Márquez, 1735. Encina y la Carrera, 1735. Pimentel de Sotomayor, 1735. 
numismático, con aspectos que requieren desentrañarse y explicarse para su debida comprensión.

Como se verá, los sucesos aquí expuestos permiten poner en cuestión la acusación de fraude. Más bien, se trató de la evolución de un conjunto de normas que, debido a algunas ambigüedades y ante la falta de vigilancia gubernamental, fueron adecuándose paulatinamente a situaciones particulares, no previstas por el legislador, y también a los intereses locales de quienes, de una u otra manera, participaban en la amonedación. En este sentido, el proceso judicial puede verse como un conflicto entre la letra expresa de la ley, defendida por los fiscales del monarca, y el peso de la costumbre.

\section{LAS REFORMAS GUBERNAMENTALES Y LA VISITA DE LA CECA MEXICANA}

El origen de los acontecimientos se halla en las preocupaciones del primer rey borbón, Felipe V, por solucionar el desarreglo monetario existente. Así, en las ordenanzas de 26 de enero de 1718 dispuso la cancelación de todas las concesiones otorgadas a particulares en España. En adelante las casas de moneda serían manufacturas reales, bajo la dirección de un superintendente. Los resultados fueron positivos, por lo cual el 9 de junio de 1728 se extendieron estas reglas a las cecas ultramarinas, con adiciones importantes: la moneda debería ser uniforme, redonda, con cordoncillo o canto labrado (lo cual implicaba una renovación tecnológica); la ley o contenido intrínseco de la plata pasaría a ser de 11 dineros, y la talla o valor que se obtenía de cada marco sería de un real más, en principio para sufragar los costos adicionales. Al frente de todas las cecas quedaría el secretario de Hacienda como juez conservador, superintendente general y presidente de la Real Junta de Comercio y Moneda ${ }^{7}$.

Fue en este contexto que el rey remitió un decreto al Consejo de Indias el 19 de junio, refiriendo los abusos muy perjudiciales que se habían cometido en las casas de moneda españolas e indianas en perjuicio de sus vasallos y de la Real Hacienda en materia que calificaba como de muy delicada y de universal importancia. Mencionaba, en particular, que la moneda mexicana arri-

7 Céspedes del Castillo, 1996: 85-90. En lo referente a la «ley» o fineza, la plata pura constaba de 12 dineros, de los cuales cada uno tenía 24 granos; esta ley era la misma para todos los valores de la moneda, variando sólo el tamaño. En cuanto al peso, la unidad era el marco de plata $(0,23 \mathrm{~kg}$.), que se subdividía en ocho onzas, o bien en 4.608 granos. Del punto de vista monetario, el peso de plata se dividía en ocho reales, cada uno compuesto (para efectos contables) por 34 maravedíes. 
bada en las últimas flotas tenía defectos tanto en el peso (los costales de mil pesos que debían tener 119 marcos y tres onzas, llegaban solamente a 117 marcos y dos onzas) como en la ley, a la cual le faltaban cuatro granos. Por esta razón, había determinado formar una ordenanza (la firmada el 9 de junio anterior) para asegurar la calidad de la moneda, así como que los virreyes procedieran con todo rigor contra los oficiales que hubiesen mal ejercido su precisa obligación ${ }^{8}$.

En consecuencia, José Patiño, como secretario de Hacienda escribió el 30 de junio al virrey de la Nueva España refiriéndole que el monarca había mostrado su extrañeza por la omisión o malicia con que se había faltado a las ordenanzas, e instruyéndole que procediera con severidad contra las personas y bienes de quienes no las hubiesen respetado9. El escrito fue recibido el 30 de diciembre por el marqués de Casafuerte, quien solicitó el parecer del fiscal de lo Civil de la Real Audiencia, licenciado Prudencio Antonio Palacios. La opinión del magistrado fue que para mejor averiguar el delito se iniciara una pesquisa reservada, presentándola como una visita o inspección de la ceca como las que de tanto en tanto acostumbraban practicarse. Al virrey le pareció bien y nombró como asesor al oidor José Fernández de Veytia Linage ${ }^{10}$.

Casafuerte acudió a la Real Casa de Moneda el 7 de febrero de 1729 acompañado del fiscal Palacios, del oidor Veytia y de su comitiva habitual. Una vez concluidas las cortesías de rigor, procedió a interrogar a todos los oficiales mayores con un cuestionario que hace evidente que alguien lo había asesorado en los aspectos legales, técnicos y administrativos del manejo de la ceca. Como correspondía, la primera declaración fue la del tesorero, el capitán Joseph Diego de Medina y Sarabia, seguido de los demás oficiales ${ }^{11}$. Varios de ellos eran «tenientes» o substitutos; ejercían el empleo por contrato con los propietarios, quienes habían adquirido sus oficios en remate público ${ }^{12}$.

8 Autos de visita y pesquisa que el virrey marqués de Casafuerte principió en la Real Casa de Moneda de esta corte, 1728, Archivo General de la Nación, México (AGN), Casa de Moneda, vol. 391, exp. 1, folios 3-5.

9 Visita que el virrey marqués de Casafuerte hizo en la Real Casa de Moneda de esta ciudad, 1728, AGN, Casa de Moneda, vol. 241, exp. 1, folios 8-10. Una averiguación paralela se realizó en la ceca limeña; véase Lazo García, 2006: 112-155.

10 AGN, Casa de Moneda, vol. 391, exp. 1, folios 7-12.

11 El tesorero pertenecía a una familia conocida por su riqueza, influencias y obras pías, que tenía posesión del oficio de tesorero desde 1663. Uno de sus hermanos era Felipe Cayetano de Medina, regidor de la ciudad, cuyos descendientes tuvieron el título de condes de Medina y Torres. Su tío y propietario parcionero del oficio, Buenaventura de Medina, construyó la suntuosa capilla familiar en la iglesia del convento de Regina Coeli. Obregón, 1971.

12 Tomás y Valiente, 1972: 151-153 y 173-177. 
Posteriormente, se hicieron también presentes fray Joseph de los Ángeles, como procurador de la provincia carmelita de San Alberto (propietaria del oficio de ensayador) y Francisco de Valdivielso, como tutor de su hijo menor Pedro de Valdivielso y Tagle, dueño del oficio de tallador (esto es, el encargado de preparar y guardar los cuños empleados para imprimir la moneda).

Tabla 1: Oficiales de la Real Casa de Moneda de MéXico, 1729

\begin{tabular}{|l|l|}
\hline \multicolumn{1}{|c|}{ Cargo } & \multicolumn{1}{c|}{ Oficiales } \\
\hline Tesorero & $\begin{array}{l}\text { Joseph Diego de Medina y Sarabia (por sí y el bachiller Ventura } \\
\text { Medina y Picazo) }\end{array}$ \\
\hline Teniente de tesorero & Manuel de Pereda Palacio \\
\hline $\begin{array}{l}\text { Tenientes de ensaya- } \\
\text { dor }\end{array}$ & $\begin{array}{l}\text { Joseph de Rivas Angulo, Joseph Eustaquio y Manuel de León (por } \\
\text { el convento carmelita del Santo Desierto) }\end{array}$ \\
\hline Teniente de tallador & Hipólito Sarmiento (por Pedro Valdivielso y Tagle) \\
\hline Balanzario & Manuel Cayetano de Elizaga \\
\hline $\begin{array}{l}\text { Tenientes de guarda } \\
\text { mayor }\end{array}$ & $\begin{array}{l}\text { Damián Pérez Vello (por Ventura Medina y Picazo); Ignacio Anto- } \\
\text { nio de Bustamante (por Juan Antonio de Urrutia, marqués del Villar } \\
\text { del Águila) }\end{array}$ \\
\hline Escribano mayor & Mateo Picardo \\
\hline Alcaldes & Antonio Meléndez Bazán; Raymundo Campoy \\
\hline Merino & Domingo Gómez Carpintero \\
\hline
\end{tabular}

Fuente: AGN, Casa de Moneda, vol. 241, exp. 1, folio 23.

La primera pregunta fue respecto del régimen de gobierno, porque aunque eran aplicables las ordenanzas castellanas de Medina del Campo (1497) y estaban vigentes las originales del virrey Antonio de Mendoza $(1535)^{13}$, estas normas habían sido modificadas posteriormente por los virreyes Luis de Velasco, Martín Enríquez y conde de Galve, así como por un visitador, el licenciado Luis de Villanueva Zapata. Con el tiempo las adiciones habían resultado en un confuso cúmulo legislativo; muchas reglas no estaban en uso y otras eran poco claras ${ }^{14}$.

En principio, los comerciantes debían presentar sus barras de plata u oro ante el tesorero y escribano, tras lo cual el guarda mayor tomaba cuenta del peso y la ley señaladas con tinta por los oficiales de hacienda de las minas y verificaba las marcas que hacían constar el pago de los reales derechos. Se-

13 Pradeau, 1953.

14 AGN, Casa de Moneda, vol. 241, exp. 1, folios 26-27. 
guidamente, el ensayador tomaba un bocado o muestra y luego de realizar el ensaye declaraba la ley de las pastas entregadas. Cuando todo estaba en orden, el guarda mayor remachaba y borraba las marcas de las barras, el balanzario o juez de balanza las pesaba y el ensayador ordenaba que pasaran a la fundición, con las correspondientes instrucciones ${ }^{15}$. El virrey halló que los oficios de ensayador y fundidor corrían juntos, sin que nadie hubiera aprobado esta unión; los oficiales dijeron que era «práctica y costumbre» de la que no se derivaba ningún inconveniente, y no había memoria que hubiera sido alguna vez de otra manera ${ }^{16}$.

La siguiente inspección fue sobre la ley de la moneda. Para este fin, Casafuerte mandó abrir la caja donde se guardaban los encerramientos. Esto es, cada partida de monedas se trasladaba desde la sala de acuñación a la de libramiento en grandes cajones cerrados con llave, cada uno capaz de contener 400 o 500 marcos. Antes de que fuesen entregadas a sus dueños, el ensayador tomaba una moneda al azar y cortaba una mitad, que volvía a examinar en presencia de todos los demás oficiales; si no cumplía con la ley, ordenaba que todas fuesen fundidas y acuñadas nuevamente. Si el ensaye resultaba correcto, el escribano guardaba la mitad restante de la moneda, con un papel donde constaba la fecha, partida y ensayador, en la caja de encerramientos ${ }^{17}$. Así pues, se sacaron las muestras y el virrey mandó que diera su dictamen Domingo Mendiola, ensayador mayor del reino, así como Joseph Eustaquio y Manuel de León, como peritos. Para mayor seguridad, ordenó también fundir todas las medias monedas para sacar un tejo o barra de cada metal, y que se extrajera un bocado que volvió a examinarse. Después de hechas las pruebas, los ensayadores dijeron que la plata tenía la ley debida de 11 dineros y cuatro granos, y el oro de 22 quilates. Posteriormente el juez de la causa tuvo mucho interés en saber si las muestras habían siempre procedido de las monedas que estaban más accesibles, o si el ensayador había tomado la precaución de revolverlas para tomar una cualquiera. Claramente, sospechaba de algún juego de manos que ocultara malos procedimientos ${ }^{18}$.

Preguntados los oficiales acerca de la forma y manera en que se entregaban las monedas, contestaron que después de acuñada y ajustada se hacía una «levada» de cincuenta en cincuenta marcos en presencia de todos los oficiales mayores para comprobar que el peso coincidiera con la plata inicialmente entregada. En el mismo acto el balanzario pesaba un marco de monedas es-

\footnotetext{
15 Recopilación..., 1982, vol. 2, libro V, tít. XXI, leyes 36 y 37.

16 AGN, Casa de Moneda, vol. 241, exp.1, folios 27-28.

17 Recopilación..., 1982, vol. 2, libro V, tít. XXI, leyes 16 y 35.

18 AGN, Casa de Moneda, vol. 241, exp. 1, folios 32-36.
} 
cogidas al azar para comprobar que hubiera en él 68 reales, utilizando una balanza de precisión y un conjunto de dinerales o pequeñas pesas de bronce ${ }^{19}$. Fueron declaraciones que inmediatamente dieron pie a que se preguntara por qué no se respetaban las leyes que disponían que las monedas se ajustaran a la talla de 67 reales por marco, y que si se labraban a 68 , se mostrara la orden o licencia correspondiente ${ }^{20}$.

En las cecas españolas se pagaban al introductor 65 reales por cada marco de plata $^{21}$. En la acuñación se agregaba un real por el «braceaje» o costo de la labor y otro por el impuesto real o señoreaje, de lo cual resultaba una talla de 67 reales. Ahora bien, en las ordenanzas fundacionales de México (1535) se había ordenado pagar los mismos 65 reales al propietario, pero por ser los gastos en las Indias «excesivos» el rey autorizó que los oficiales llevaran tres reales de derechos «hasta que más informados proveamos en ello lo que convenga», porque de otra manera «no podrían ni buenamente querrían labrar la dicha plata, por no tener congrua sustentación». Posteriormente, en 1567, se previno que podría convenirse que en estos tres reales quedara incluido el derecho real o señoreaje, de modo que quedasen dos para los oficiales ${ }^{22}$. La norma, tal como quedó y fue finalmente incluida en la Recopilación de leyes de Indias, admitía distintas interpretaciones, sobre todo porque de hecho el señoreaje no comenzó a cobrarse sino hasta 1615 y en 1698 pasó a recaudarse directamente en los reales de minas ${ }^{23}$. El asunto tenía relevancia porque esta diferencia de un real, multiplicada por cada marco acuñado, sumaba una considerable cantidad que alguien debía de embolsarse. En este mismo año de 1729 , por ejemplo, se habían acuñado $893.286 \operatorname{marcos}^{24}$ y por lo mismo

19 Un ejemplo de estos dinerales puede observarse hoy día en el Muséu de Prehistoria, en Valencia.

20 AGN, Casa de Moneda, vol. 241, exp.1, folios 39-40.

21 Recopilación..., 1982, vol. 2, libro V, título XXI, ley 5.

22 Encinas, 1945-1946, vol. 3: 225. El texto (que es una síntesis de mandamientos anteriores), quedó en estos términos: «Porque según las ordenanzas de las casa de moneda de estos reinos de Castilla se han de sacar de cada marco de plata sesenta y siete reales, de los cuales se reserva uno para todos los oficiales, y por ser los gastos de las Indias excesivos, conviene darles mayor recompensa para que mejor puedan acudir a su trabajo, y tengan congrua sustentación: Mandamos que los oficiales de las casas de moneda de las Indias puedan llevar y permitimos que lleven de cada marco de plata que en ellas se labrare, tres reales, los cuales se den y repartan entre los susodichos en la misma forma que a los de estos reinos, excepto si se concertare y conviniere por asiento, que en este caso ha de quedar incluido el señoreaje y monedaje, de tal manera que los dos reales sean por los costos y costas, y el otro para el señoreaje». Recopilación..., 1973, libro IV, tít. XXIII, ley 8.

23 Elhuyar, 1979: 2-3.

24 Céspedes del Castillo, 1996: 251-254. 
debió haber otros tantos reales de diferencia. Reducida esta cantidad a la unidad monetaria usual, eran 111.660 pesos, una cantidad nada despreciable.

El tesorero Medina parece haber replicado con cierta incomodidad, como alguien que sabe puede estar en falta. Mencionó que cuando tomó posesión del oficio, en 1713, notó que la moneda no se ajustaba a los 67 reales previstos por la entonces más reciente versión de las ordenanzas, del tiempo del virrey conde de Galve (1693). Por esta razón, había hecho llamar a los empleados más viejos, quienes informaron que efectivamente se practicaba la acuñación a 68 , sin que hubiera memoria desde cuándo. Después de considerar este delicado asunto, el tesorero, los oficiales mayores y alcaldes acordaron que en la primera ocasión posible representarían al virrey las dudas sobre esta norma, así como sobre otras que consideraban «inútiles e impracticables, sin uso, ni ejercicio». Así se hizo cuando Casafuerte visitó por primera vez el establecimiento en junio de 1723 . El virrey, con parecer del fiscal de la Real Audiencia, Pedro Malo de Villavicencio, mandó como se pedía y que al siguiente año se imprimieran las nuevas y corregidas ordenanzas. Entre las modificaciones estuvo, precisamente, que la talla se haría en lo sucesivo a 68 reales ${ }^{25}$.

Respecto del peso de la moneda, dijeron los oficiales que los 1.000 pesos labrados sobre el «pie» de 67 reales por marco debían tener aproximadamente 119 marcos y 3 onzas, mientras que sobre 68 correspondían a 117 marcos 5 onzas, con una variación que dependía del feble o fuerte, esto es, la corta tolerancia permitida por las ordenanzas, que era un tomín y medio (equivalente a 0,89 gramos) por marco de plata ${ }^{26}$. El último cálculo correspondía en general al peso observado en las monedas de la última flota de Indias.

Como es obvio, la diferencia de peso incidía en la cantidad de monedas que se obtenía de un marco. Las ordenanzas castellanas mandaban que hubiera una caja donde se depositara el exceso que resultaba cuando salía feble, y que su importe se empleara en obras públicas. Lo mismo se dispuso para Indias, aplicándose a las doctrinas y misiones ${ }^{27}$. Interrogados al respecto, los oficiales dijeron que aquí no había tal caja, dado que la moneda se entregaba por peso y no por cuenta individual. Era algo esperable, dado que el conteo individual habría sido muy laborioso por la mayor producción de la ceca mexicana, pero esto resultaba en que el posible feble beneficiara a los introductores y no a la Real Hacienda ${ }^{28}$.

25 AGN, Casa de Moneda, vol. 241, exp. 1, folios 40-43.

${ }_{26}$ Ibidem, folio 43. Técnicamente, una moneda podía considerarse feble también por su deficiente ley, pero este aspecto no fue considerado como tal en el proceso.

27 Recopilación, 1973, libro IV, tít. XXIII, ley 23.

28 AGN, Casa de Moneda, vol. 241, exp. 1, folio 45. 
El 9 de febrero de 1729 Casafuerte declaró que en razón de sus múltiples y graves ocupaciones delegaba la continuación de la visita en el oidor Veytia. Era éste un funcionario capaz, ambicioso y enérgico, perteneciente a un ilustre linaje de oficiales del rey ${ }^{29}$. Sus méritos le valdrían para ser nombrado el 16 de marzo de 1729 como primer superintendente o director de la Real Casa de Moneda, al tiempo que proseguía con las averiguaciones ${ }^{30}$. Así, tuvo que contar con la colaboración de los mismos oficiales investigados para mantener la ceca en producción, lo cual no debió ser fácil.

El oidor pasó ese mismo día a la oficina de la talla para preguntar por qué razón la moneda aparecía con tantos defectos de impresión, al punto que no se veían bien las armas reales ni menos se percibía el año, la marca de la ceca y la inicial del ensayador, dispuestas todas para que pudiera prevenirse y castigar cualquier fraude. Los guardas mayores Pérez Vello y Bustamante dijeron que el motivo de que faltaran frecuentemente dichos elementos era que la moneda labrada tenía menor diámetro que la pila (donde se asentaban los cospeles o discos) y el troquel (con el que se golpeaba para imprimir la moneda). Por su parte, la debilidad del estampado se debía a que cuando había urgencias porque llegaban las flotas de España o el navío de Filipinas, los acunadores realizaban su labor con demasiada prisa y aún se les mandaba que no perdieran tiempo, con las inevitables consecuencias. Ninguna de las dos razones dejaba bien parados a los oficiales ${ }^{31}$.

Veytia mandó asimismo pedir varias talegas con monedas de diferentes denominaciones de la casa del mercader Francisco de Valdivielso. Traídas, mandó se contasen y que el balanzario pesara cantidades de mil pesos, cada tipo separadamente. El resultado fue que, con alguna variación, correspondían al peso que debían tener, siempre y cuando se ajustara la talla a 68 reales (véase tabla 2$)^{32}$.

El 19 de febrero el visitador pasó a inspeccionar la escribanía para tratar de dilucidar la cuestión de la talla a partir de los registros contables. Halló que desde 1706 hasta 1709 constaba que había sido de 67 reales. Entre 1709 y 1711 no había libros, aparentemente porque un anterior teniente de escribano los había llevado a su casa para revisarlos durante una enfermedad y de ahí fueron misteriosamente robados. Después de 1711 cambiaba el estilo y sólo se refería que las acuñaciones habían sido hechas «al peso y precio acostumbrados». Finalmente, desde julio de 1723 hasta fines de 1728 reaparecía

\footnotetext{
29 Bertrand, 1999: 345-350.

30 González Gutiérrez, 1997: 144.

31 AGN, Casa de Moneda, vol. 241, exp. 1, folios 46-49.

32 Ibidem, folio 51.
} 
la constancia de la talla precisa, esta vez fijada a 68 reales por marco de plata, sin que hubiera razón alguna de estas variaciones. Eran cosas que el visitador pensaba eran «formalísima transgresión de leyes y ordenanzas» ${ }^{33}$.

\section{LA CAUSA CRIMINAL}

Finalmente, Veytia dispuso el 8 abril de 1729 lo que debía ser ya un secreto a voces, esto es el inicio de un juicio criminal por delitos que consideraba ya suficientemente probados ${ }^{34}$. Sin embargo, no hubo movimientos judiciales durante varios meses. Esto probablemente se debió a que Veytia - en sus funciones como superintendente- estuvo muy ocupado con el establecimiento de la «nueva planta» de la ceca, y también con las objeciones y renuencias de los oficiales. Éstos, encabezados por el tesorero Medina, pidieron que se suspendiera la ejecución de las ordenanzas porque había dudas entre otras cosas acerca de si la nueva moneda, de menor ley, correría con el mismo valor que la antigua; y si la disposición de que se añadiera un real a la talla implicaba llevarla a 69 reales. Dijeron también que la nueva impresión, por ser más elaborada, provocaría una reducción de la acuñación con perjuicio de los comerciantes e incluso del tráfico de las flotas, además de dejar menores provechos a los oficiales y por tanto depreciar el valor de sus oficios. Se atrevieron incluso a hablar (con muchas protestas de veneración y respeto al monarca) de defraudación en su contra, con motivo de que los contratos firmados al momento de la concesión los obligaban tanto a ellos como al rey. Por su lado, los comerciantes Francisco de Valdivielso y Francisco de Fagoa$\mathrm{ga}^{35}$, que eran los mayores introductores de plata, suspendieron la entrega durante varios meses con el motivo (o pretexto, más probablemente) de que estaban en espera de la resoluciones sobre la nueva labor, lo cual desde luego afectaba a la Corona en un flanco fiscal muy sensible ${ }^{36}$. Debe notarse que

33 AGN, Casa de Moneda, vol. 391, exp. 1, folios 36-38.

34 Ibidem, folios 42-43.

35 Francisco de Valdivielso fue yerno, hombre de confianza y albacea (desde 1723) del gran propietario de tierras, comerciante y prestamista Pedro Sánchez de Tagle, y fue quien continuó sus tratos en el comercio de la plata; Goyas Mejías, 2011: 72-73. Por su parte, Francisco de Fagoaga fue un migrante guipuzcoano que hizo una inmensa fortuna en el comercio y financiamiento de la minería; Pérez Rosales, 2003: 17-25. En cuanto a la vinculación de los mercaderes de plata en general con la Real Casa de Moneda, consúltese Valle Pavón, 2011.

36 Autos hechos en ejecución de real orden sobre la ley, peso, estampa y demás circunstancias con que se han de labrar las monedas de oro y plata en este reino, 1728, AGN, Casa de Moneda, vol. 270, exp. 2, folios 71-86. 
Fagoaga, además, tenía la posesión del oficio de apartador de oro desde 1712, que en un taller aparte manejaba la lucrativa e indispensable separación de este metal ${ }^{37}$.

El fiscal Palacios respondió con una refutación de todas las objeciones y negándose a la menor concesión. Como parte de su argumento incluyó una reflexión que es de interés porque después sería retomada en el proceso judicial. Sostuvo que la pasada acuñación en 68 reales se debía a una maliciosa interpretación de las leyes, porque el justo valor del marco de plata tal como era pagado al productor era de 64 reales (y más recientemente, en México, de 64 y una cuartilla) y por real concesión, para que tuvieran ganancias los introductores, se había permitido que recibieran 65 . Consideraba que haber dado 66 reales a los mercaderes era un abuso, y que de esto habían recibido provechos «inmensurables», porque eran muy crecidas las sumas acuñadas ${ }^{38}$.

En agosto de 1729 Veytia comenzó una extensa ronda de interrogatorios dirigida a personas que fuesen «inteligentes por haber asistido y servido en dicha real Casa y en las de los mercaderes de plata ${ }^{39}$. Las preguntas fueron más específicas, abordando cuestiones que los oficiales mayores habían dejado convenientemente en la imprecisión y vaguedad; varias de ellas suponían ya malos manejos. Los testigos convocados fueron cajeros o administradores de los grandes comerciantes, entre los cuales el más notable fue el teniente coronel Francisco Antonio Sánchez de Tagle, gran mercader de plata, prior o máxima autoridad del poderoso Consulado de Comerciantes, y que previamente había sido durante 20 años administrador y apoderado de sus parientes, Luis y Pedro Sánchez de Tagle, marqueses de Altamira ${ }^{40}$. Asimismo, fueron citados un par de antiguos acuñadores y nueve capataces que estaban o habían estado a cargo de las «hornazas» o fundiciones. Eran hombres que frecuentemente se habían formado en la misma ceca pasando por los distintos oficios, como el maestro Nicolás de Espinosa, quien había ingresado como aprendiz a la edad de 10 años y luego se había desempeñado otros 35 como oficial de brazajero, hasta que los últimos cinco había sido promovido a capataz ${ }^{41}$.

En este cúmulo de testimonios el juez encontró varias adecuaciones a las normas, algunas situaciones que parecían irregulares y otras que le resultaron muy sospechosas. Los alcaldes debían asistir al menos dos días por semana,

37 Sobre la relación de los Fagoaga con el Apartado, véase Sanchiz, 2000; debe notarse que esta empresa no fue incluida en la visita y posterior causa judicial.

38 AGN, Casa de Moneda, vol. 241, exp. 1, folios 93-97.

39 Ibidem, folios 92-96.

40 Ibidem, folio 254.

41 Ibidem, folios 302-303. 
alternándose en sus labores para resolver cualquier asunto de justicia y visitar a los presos de la cárcel. Los testigos parecen haberlos visto rara vez, sólo cuando eran llamados por algún asunto. En realidad, eran letrados que tenían el cargo como una especie de beneficio lateral de sus principales ocupaciones; Campoy, por ejemplo, era relator de la Real Audiencia. También según las ordenanzas, los alcaldes y demás oficiales debían reunirse una vez por mes para atender los asuntos de buen gobierno de la ceca y tomar las disposiciones pertinentes. Esto había dejado de tener lugar; se consideraba innecesario porque se veían de manera cotidiana. Respecto de la cárcel, nadie había visto que sirviera sus funciones propias, a no ser un testigo que se refirió vagamente a un caso, en fecha muy remota ${ }^{42}$.

Otras prácticas resultaban de un procedimiento que era propio de la Real Hacienda, pero que en este caso había derivado en beneficios privados. En las últimas décadas del siglo XVI la Corona, presionada por sus urgencias fiscales, aceptó la venta de muchos oficios públicos, que se otorgaban por remate, de manera vitalicia y hereditaria. Esto fue así con los oficios mayores de la Real Casa de Moneda y trató de extenderse a los menores, como los acuñadores $^{43}$. Sin embargo no fue posible, porque se trataba de puestos de los que solamente podían obtenerse moderados ingresos y el tesorero los daba supuestamente de gracia. Ahora bien, varios oficiales declararon que para suceder en un oficio de acuñador o capataz habían tenido que pagar distintas cantidades. Éstas habían sido por dos conceptos: por un lado, «composiciones» con viudas o renunciantes, sobre lo que era costumbre dar 1000 pesos por un cargo de capataz, acuñador o brazajero (incluso se mencionaron sumas de hasta 4000 y 5000 pesos, aunque fueron testimonios de oídas). Y por otro, pagos a los tesoreros por el nombramiento, en cantidades de 500, 600 y 800 $\operatorname{pesos}^{44}$.

Todas estas irregularidades eran relativamente menores dado que no afectaban directamente al real patrimonio, y podrían haberse resuelto con una amonestación y multas de mayor o menor entidad. Desde el punto de vista del juez era mucho más grave que, como descubrió, el ensayador no realizara varias de las labores que teóricamente estaban a su cargo. Como dejó testimonio Juan Claros, el hombre de confianza del antiguo banquero Isidoro Rodríguez de Lamadriz, eran los cajeros de los mercaderes quienes se aseguraban que la ley marcada en las barras por los ensayadores de las minas fuese la correcta, disponían la aleación del metal, daban instrucciones al

42 Ibidem, folio 281.

43 Recopilación..., 1973, libro VIII, título XX, ley 1 y libro IV, título XXIII, ley 14.

44 AGN, Casa de Moneda, vol. 241, exp. 1, folios 151-152 y 183. 
maestro fundidor y en general supervisaban la fundición. También tenían cofres donde guardaban sus platas u oros en la misma ceca, con llaves que permanecían en su poder ${ }^{45}$.

Los ensayadores se limitaban a recaudar los derechos por una labor que, en realidad, llevaban a cabo sólo a medias. Esto es, después de fundidos los metales y antes de la amonedación, pasaban a tomar un bocado de cualquiera de los «rieles» resultantes y comprobaban que la ley fuese la dispuesta por las ordenanzas; si no era así, procedían a «condenarlos» a volverse a fundir, en su presencia. Las únicas labores que desde el principio estaban bajo su dirección eran las de oro, que siempre fueron (en porcentaje) cantidades relativamente menores ${ }^{46}$. El sistema de vigilancia escrupuloso y redundante, que era típico de las casas de moneda, se había simplificado notablemente, lo cual podía dar lugar a maniobras fraudulentas.

Otras prácticas también llamaron la atención del juez. En efecto, descubrió que los mercaderes entregaban «dádivas» a los oficiales. Como declaró el banquero Valdivielso, daban al ensayador, aparte de los derechos previstos por ley, un peso por cada crazada o carga de fundición, y a los oficiales 6 u 8 pesos por cada libranza «por el motivo de que en ofreciéndose un despacho se les precisa a que den doblada plata en cada semana, por la urgencia» y que por esto madrugaban y "se incomodan de sus horas» ${ }^{47}$. El juez barruntó que en realidad era para que disimularan la falta de ley y de peso, que favorecía a los introductores porque recibían más monedas por cada marco de plata. De poco sirvió que el ensayador Rivas Angulo dijera que era costumbre inmemorial, y que por recibir estos gajes no les dispensaban de cosa alguna ${ }^{48}$.

En el caso de los capataces, los mercaderes les daban dos ochavas por cada 50 marcos de plata. Este punto salió a luz debido a que reclamaron ante Veytia porque a partir de la ejecución de la «nueva planta» los comerciantes habían dejado de entregárselas. Dijeron en su queja que el pago era para compensar las mermas que sufrían los metales en el proceso de fundición, así como porque en algunas urgencias, como las que provocaban la llegada de las flotas, tenían que trabajar incluso feriados y domingos. Veytia desestimó esta demanda porque no había nada en las ordenanzas que la justificara, pero le llamó la atención porque en principio las razones alegadas para esta propi-

\footnotetext{
45 AGN, Casa de Moneda, vol. 391, exp. 1, folios 68-73.

46 Ibidem, folios 113-119.

47 Testimonio de los autos y confesiones de los mercaderes de plata, 1732, AGN, Casa de Moneda, vol. 362, exp. 6, folio 86.

48 Confesiones del tesorero de la Casa de Moneda, de los alcaldes y oficiales mayores de ella, 1730, AGN, Casa de Moneda, vol. 391, exp. 2, folios 180-188.
} 
na no habían desaparecido con el cambio a la administración real. Sospechó que en realidad haba sido una especie de soborno para que los capataces produjeran mayores febles de lo permitido. Si era así, la suspensión del pago tenía mucho sentido, porque las nuevas ordenanzas preveían que la diferencia originada en el feble pasara ahora a la Real Hacienda ${ }^{49}$.

Al mismo tiempo, el juez hizo averiguaciones sobre los dinerales que servían para calcular cuántos reales se sacaban por marco de plata. Los capataces interrogados estuvieron contestes en decir que los antiguos habían sido sustituidos por el balanzario Elizaga en 1724 o 1725, en razón aparentemente de que estaban ya muy gastados o perdidos, y quedaron desde entonces ajustados a 68 reales. Respecto del ajuste anterior de la talla, los capataces, que obviamente debían tener una experiencia y conocimiento directo, dieron testimonios muy diversos. Algunos dijeron que la de 68 era «costumbre inmemorial» y otros fueron muy vagos y contradictorios al respecto, ya fuese en razón de que no lo tenían claro o porque temieran las posibles consecuencias ${ }^{50}$.

En cambio, nada resultó de preguntas que apuntaban a fraudes y delitos muy graves, como la posible acuñación de plata sin haber pagado los correspondientes derechos al rey. E interrogados los testigos sobre los procedimientos y conducta de los oficiales mayores, todos a una dijeron que eran conocedores de su oficio, muy escrupulosos, que «obraban cristianamente», «con pureza y legalidad» $»^{51}$.

En cuanto a la ley y peso, Veytia hizo traer monedas de la Caja de Bienes de Difuntos ${ }^{52}$. La razón era que en esta institución solían permanecer los caudales durante bastante tiempo, de modo que podían encontrarse monedas acuñadas varios años atrás. Examinadas por el teniente de ensayador mayor Francisco de la Peña, resultó que en unas faltaban seis granos y en otras dos, y el peso de las talegas era variable, con algunas por debajo de lo esperado. El juez se negó a que los acuñadores, capataces y otros oficiales reconocieran si estas monedas ensayadas eran las fabricadas en México (a veces se hallaban monedas de otros reinos), so excusa de conflicto de intereses y afección al tesorero. Tampoco aceptó que el tesorero pidiera las monedas para ensayarlas por su cuenta, o al menos que se le diera testimonio de los autos ${ }^{53}$.

49 Los capataces de la Real Casa de Moneda de esta corte sobre que los mercaderes de plata les continúen a dar dos ochavas de plata en cada 50 marcos que labran, 1729, AGN, Casa de Moneda, vol. 422, exp. 1, folios 2-45.

50 AGN, Casa de Moneda, vol. 241, exp. 1, folios 303-308.

51 Ibidem, folios 207 y 238.

52 Sobre esta Caja, véase Enciso Contreras, 2000.

53 AGN, Casa de Moneda, vol. 241, exp. 1, folios 313-322. 
TABla 2: Resultado De Distintos PeSAJES DE TAlegas CON MIL PESOS DE PLATA

\begin{tabular}{|l|l|}
\hline \multicolumn{1}{|c|}{ Procedencia } & \multicolumn{1}{c|}{ Levada de mil pesos } \\
\hline Peso legal con 67 reales & 119 marcos, 3 onzas \\
\hline Peso con 68 reales & 117 marcos, 5 onzas \\
\hline Flota de indias en Sevilla & 117 marcos, 2 onzas \\
\hline Francisco de Valdivielso, monedas de ocho reales & 117 marcos, $3 \frac{1}{2}$ onzas \\
\hline Francisco de Valdivielso, monedas de un real & 116 marcos, 7 onzas \\
\hline Caja de Bienes de Difuntos, monedas de ocho reales & 117 marcos, 2 onzas \\
\hline Caja de Bienes de Difuntos, monedas de medio real & 113 marcos \\
\hline
\end{tabular}

Fuente: Basado en los documentos citados en este artículo.

Finalmente, el juez citó a los mercaderes de plata, Valdivielso, Fagoaga y Lamadriz. El 13 de septiembre de 1729 se presentó Valdivielso. Se mostró sorprendido cuando fue preguntado por qué el ensayador no se ocupaba del primer ensaye y disposición de la debida aleación; creía que siempre lo habían hecho los cajeros y administradores de los banqueros. En todo caso, declaró, todo se realizaba con la mayor legalidad y fidelidad. En cuanto al ajustamiento de la talla de las monedas, no era algo que estuviera a su cargo, dado que él las recibía por peso y no por cuenta. Sabía que el valor propio del marco era de 65 reales, pero los introductores recibían un real más para gastos de fundición, salarios de sirvientes y derechos del ensayador porque de otra manera, según dijo, no habría nadie que llevara la plata a amonedar, pudiendo venderla en pasta por la misma cantidad ${ }^{54}$.

Fagoaga declaró al día siguiente que tenía por innecesario que el ensayador realizara el ensaye al recibirse las platas. En cuanto a la talla, dijo que entre 1705 y 1708 él había tenido la comisión de la amonedación de la plata que recaudaba la Real Hacienda por distintos conceptos, pero en ese último año había pasado a hacerla el contador Joseph de Urrutia. Era este oficial quien habría persuadido al teniente de tesorero Manuel de Pereda y Palacio para que el marco se dividiera en 68 reales. Esto es, la irregularidad, si existía, habría comenzado con la misma plata del rey, sin que nadie pusiera objeciones. Posteriormente, el banquero haría constar que había sido comerciante de metales preciosos sólo desde 1727, por lo cual las monedas halladas en falta en España no podían ser suyas ${ }^{55}$.

\footnotetext{
54 AGN, Casa de Moneda, vol. 362, exp. 6, folios 48-57.

55 Ibidem, folios 57-70.
} 
Fagoaga no se contentó con su declaración judicial. En efecto, poco después Casafuerte envió al rey un inusual informe sobre su persona, haciendo constar que era uno de los principales vecinos y republicanos, dueño de un banco de plata, que había colaborado de forma destacada con la Real Hacienda (era el autor de unas «tablas» usadas para calcular impuestos mineros), presidido el influyente Consulado de Comerciantes y hecho un cuantioso donativo al rey, además de haberse encargado del Apartado con puntualidad y exactitud. El monarca mandó dar las gracias a Fagoaga y prometió atenderlo a proporción de sus méritos ${ }^{56}$. No era algo que tuviera directa relación con la causa, pero sin duda incidió en ella.

En cuanto a Lamadriz, el escribano hizo constar que en su residencia siempre le decían que se hallaba fuera de la ciudad. La verdadera razón, declaró, era que se hallaba «fallido y quebrado», con sus bienes embargados y ocultándose de sus acreedores ${ }^{57}$. El trato de la plata, como puede verse, podía hacer pero también deshacer fortunas.

\section{APREHENSIONES, EMBARGOS Y CONSECUENCIAS INESPERADAS}

El 15 de noviembre de 1729 Veytia opinó que en la pesquisa había materia suficiente para poner acusación en forma, así como realizar las correspondientes aprehensiones y embargo de bienes de los reos. Respecto a la duda sobre si proceder de esta manera causaría escándalo en la ciudad y provocaría problemas en las labores cotidianas de la ceca, replicó que el oficio de un juez era la justicia, y no la misericordia. En todo caso, si era necesario, el virrey podía nombrar oficiales interinos. Tenía prisa el magistrado aunque este apresuramiento pudiera dar lugar a que los encausados protestaran y pudieran pedir, como hizo notar el fiscal Palacios, la anulación de los autos por violación del debido proceso ${ }^{58}$.

Alguien debió insinuarle a Veytia que corría el riesgo de paralizar la labor en la Real Casa de Moneda, con graves consecuencias, porque el 9 de febrero de 1730 escribió al virrey para decirle que lo que urgía era dar salida a la gran suma de barras de plata que habían introducido los mercaderes para su amonedación, con el fin de atender al despacho de la flota por entonces fon-

56 Real cédula por la cual el rey da las gracias a Francisco de Fagoaga, 24 de febrero de 1732, AGN, Vínculos y Mayorazgos, vol. 8, exp. 4, folios 199-203.

57 AGN, Casa de Moneda, vol. 362, exp. 6, folio 73.

58 Representación de Joseph Fernández de Veytia al virrey, 2 de junio de 1730, AGN, Casa de Moneda, vol. 62, exp. 10, folios 159-161. 
deada en Veracruz. Propuso que se suspendieran de momento las aprehensiones y embargos, y así lo aprobó Casafuerte ${ }^{59}$.

Finalmente, el 22 de junio de 1730 el merino Gómez Carpintero embargó los bienes de los oficiales, así como los ingresos que fuesen consecutivamente acumulándose por concepto de derechos de amonedación. Los afectados apelaron al virrey, pero el mandatario determinó que no había lugar, con excepción del oficio de ensayador, del que se sustentaba el convento carmelita. Veytia dispuso entonces que se valuara el promedio de los ingresos netos de los oficiales en el último quinquenio, para adjudicarles las cantidades necesarias para los alimentos justos y correspondientes a sus personas y empleos ${ }^{60}$.

El embargo acabó afectando a terceros, como era de esperarse en una economía donde las operaciones financieras y crediticias eran amplias y entrelazadas. Un tesorero anterior, Francisco de Medina y Picazo, había establecido en 1688 una obra pía para dote de dos huérfanas que asistieran a la festividad de la Virgen de Guadalupe, sostenida con 6000 pesos de principal sobre el valor del oficio. Al embargarse los bienes de su sucesor, dejaron de entregarse los réditos de 300 pesos anuales. El Obispado hizo diligencias extrajudiciales para que se efectuase el pago y así lo aprobó Veytia, con el precavido detalle de que no se descontaría de los ingresos del oficio, sino de las sumas dadas al tesorero por concepto de alimentos ${ }^{61}$.

Más enredado e interesante fue el caso planteado por los banqueros Fagoaga y Valdivielso, quienes reclamaron que el tesorero Medina les debía 29.543 pesos de pasadas acuñaciones. Ocurría que aunque en principio la ceca debía entregar las monedas a los introductores al final del proceso de acuñación, en la práctica esto no era así. Los tesoreros dilataban el pago, de modo que acumulaban un adeudo considerable que liquidaban a fin de año; en términos económicos, era un financiamiento indirecto a corto plazo. Este acuerdo causó serios problemas cuando Veytia determinó el embargo de los bienes del tesorero, que ahora no tenía cómo pagar. Medina culpó a los ocho capataces por deberle 30.901 pesos, que pedía fueran obligados a entregarle; de esto, decía, procedía su deuda con los mercaderes y no de «delito, usurpación o voluntaria disipación». Si no era posible, Medina proponía que lo adeudado se obtuviera de los derechos retenidos del oficio, dado que el rey debía ser

\footnotetext{
59 AGN, Casa de Moneda, vol. 241, exp. 1, folio 361.

60 Ibidem, vol. 62, exp. 10, folios 161-164.

61 Carta suplicatoria del juzgado de capellanias, 1737, AGN, Casa de Moneda, tercera serie, vol. 655, exp.1152, cartera 25.
} 
considerado como sucesor de la tesorería, con obligaciones subrogadas ${ }^{62}$. Veytia no estuvo de acuerdo y declaró que el deudor debía pagar sin dilación, pero nada consiguió. El litigio acabó por agriar ánimos ya muy indispuestos y el juez tuvo motivos para quejarse de que las partes habían presentado escritos con cláusulas malsonantes, acusándolo de apasionado y de mala fe, cuando solamente había procedido según su conciencia. Los banqueros no tuvieron más recurso que acudir ante el rey, y el caso se empantanó durante varios años ${ }^{63}$.

También debería haberse procedido al embargo de los bienes de los banqueros Fagoaga y Valdivielso. No se atrevió Veytia a ir tan lejos porque, como declaró:

... si con ellos se intentase hacer novedad por el mismo hecho cesaría universalmente en este reino la labor de las minas, porque de sus dos bancos pende el avío y corriente de ellas, son como unos arcarios generales de los mineros, a quienes adelantan y suplen muchas cantidades y el beneficio público que proviene de esto no necesito yo ponderarlo.

El juez se contentó con que exhibieran una fianza y que prometieran presentarse cuando fuesen llamados ${ }^{64}$.

En principio, todos los oficiales deberían haber sido recluidos en la estrecha y húmeda prisión de la propia Real Casa de Moneda. No obstante, Veytia hizo la concesión de que guardaran prisión domiciliaria, con advertencia de fuertes penas en caso de quebrantarla, como se acostumbraba con personajes «de calidad». Por otro lado, siguieron sirviendo sus oficios, yendo diariamente desde su lugar de reclusión a la ceca. La excepción fue el teniente de ensayador Rivas Angulo, a quien Veytia consideró como renuente a declarar la verdad, por lo cual determinó "agravarle" la prisión poniendo soldados en su puerta, cuyos salarios debía pagar el reo. El ensayador dijo que carecía de medios y ofreció ya fuese dar fianza para permanecer en su casa o ser recluido en la cárcel del establecimiento. Esto último fue lo preferido por el juez ${ }^{65}$.

En cambio, el marqués de Villar del Águila, propietario del oficio de guarda mayor, recibió un trato de preferencia. Cuando fue notificado de la acusa-

62 Francisco de Valdivielso y Francisco de Fagoaga contra Joseph de Medina y Sarabia, 1733, AGN, Judicial, vol. 16, exp. 14, folios 167-169. Como puede verse, el sistema de crédito indirecto se extendía al interior de la ceca.

63 El virrey da cuenta a su majestad del cumplimiento de real cédula, 1739, AGN, Casa de Moneda, vol. 297, exp. 10, folios 212-239.

64 AGN, Casa de Moneda, vol. 362, exp. 6, folios 45-46.

65 Ibidem, vol. 391, exp. 2, folios 291-293. 
ción, dijo que no podía acudir porque estaba atendiendo las obras de la conducción del agua de Querétaro, esto es, el gran acueducto que sostenía con su propio peculio y que llegaría a ser emblema de la ciudad. En su lugar, guardó prisión domiciliaria su representante legal ${ }^{66}$.

Además de los oficiales actuales, el juez ordenó la aprehensión del licenciado Joseph Méndez, quien había sido alcalde cuando se modificaron las ordenanzas en 1724; su colega de entonces, Gerónimo Hernández de Gracia, se salvó por haber ya fallecido ${ }^{67}$.

Los meses siguientes se ocuparon en peritajes y en las declaraciones de los acusados y de diversos testigos. Entre las más interesantes estuvo la del tesorero Medina, que se efectuó entre el 1o. y el 13 de julio de 1730. Dijo que la ley de la moneda no era su responsabilidad sino la del ensayador, y se remitió a los re-ensayes hechos en la misma ceca, que habían salido correctos. En cuanto a la talla, siempre se habría labrado la moneda a 68 reales y el peso hallado en las talegas en España era el correspondiente. En todo caso, consideraba que «en materia tan antigua siempre se presume haber habido justas causas para su introducción, de tal suerte que no se necesita buscar el origen, raíz o razón». Respecto de los registros del escribano que mostraban que se había hecho a 67 reales hasta 1709, lo atribuía a «error manifiesto y falta de inteligencia», por haber seguido el estilo de la casa de moneda de Segovia. Finalmente, sostuvo que si se habían llevado derechos ilegales por conceder los oficios menores, habría sido en el tiempo de sus antecesores, porque él no lo había permitido ${ }^{68}$.

El 29 de noviembre de 1730 Veytia decidió que en la pesquisa sumaria, confesiones y testimonios había suficiente materia para realizar un auto de cargo y prueba. Los cargos fueron nueve, aunque algunos posteriormente tuvieron acusaciones derivadas.

Primero: que se había experimentado desde hacía algunos años abusos perjudiciales al real servicio y contravención a las ordenanzas en la labor de las monedas, de lo cual resultaban culpados todos los oficiales mayores y los mercaderes de plata. Estrictamente hablando, los responsables eran el tesorero y el ensayador, pero el juez consideró como presuntos culpables a todos los oficiales, dado que habían jurado guardar y hacer guardar las ordenanzas (el único que se salvó fue el merino Gómez Carpintero, algo que los defensores no dejaron de notar con cierta ironía). Veytia fue aún más allá. Sostuvo que los mercaderes como Domingo de Larrea, Luis y Pedro Sánchez de Tagle,

\footnotetext{
66 Ibidem, folios 443-450.

67 Ibidem, vol. 391, exp. 2, folios 373-374.

68 Ibidem, folios 163-180.
} 
Nicolás López de Landa, Isidro Rodríguez de Lamadriz (algunos ya fallecidos, otros que habían abandonado el trato), y después Valdivielso y Fagoaga, se habían beneficiado del delito, por lo que correspondía proceder contra los dos últimos. Oficialmente, los muy ricos e influyentes «banqueros» de plata pasaron a ser reos sometidos a un juicio criminal, algo que debió causar conmoción en la capital virreinal ${ }^{69}$.

El segundo cargo era sobre la falta de peso de las monedas, en que salían responsables el balanzario, guardas mayores y más gravemente el tesorero, por haber entregado la moneda por peso; y asimismo los mercaderes, por cooperadores del delito, y en quienes se derivaba la utilidad.

El tercero fue sobre haberse labrado y tallado la moneda sobre el dineral de 68 reales, por lo cual procedía actuar contra el tesorero, guardas mayores, ensayadores, balanzario y escribano, así como contra los comerciantes.

El cuarto se derivaba del feble sacado de la moneda, y sobre no haber tenido caja para guardarlo. El quinto era acerca de haber llevado el tesorero derechos o regalías en el nombramiento de los oficiales menores. El sexto, sobre que por omisión o descuido se habían sustraído del archivo los libros y papeles de las libranzas despachadas entre 1709 y 1711.

El séptimo y octavo resultaron contra los guardas mayores, por no haber estado presentes en la entrega y sustitución de las pilas y troqueles con que se acuñaba la moneda (muchas veces acudía solamente uno, por sus múltiples ocupaciones); y mala estampa de la misma.

El noveno fue contra los alcaldes, sobre no haber asistido los días primero de cada mes a las juntas con los demás oficiales mayores, dispuestas por ordenanzas $^{70}$.

Medina encargó su defensa a al procurador Francisco Xavier Márquez y al licenciado Joseph Méndez. Uno de sus argumentos principales atacó el fundamento mismo de la acusación. En efecto, en el real edicto que dio origen a la pesquisa y posterior proceso se hablaba genéricamente de defectos en las monedas que habían llegado en la flota, pero no constaban casos específicos ni si estas monedas habían sido acuñadas en el período de funciones de los oficiales acusados. Aun si este fuese el caso, podían ser obra de falsificadores y cercenadores, para cuyo fundamento citaban numerosas causas criminales, de las cuales después presentaron copias certificadas ${ }^{71}$. Lo mismo podía decirse de las monedas procedentes de la Caja de Difuntos, donde Veytia no

\footnotetext{
69 Ibidem, vol. 362, exp. 6, folios 44-45.

70 Encina y la Carrera, 1735.

71 Francisco Xavier Márquez, en nombre de Joseph Diego de Medina y Sarabia, solicita testimonio de causas por falsificación de moneda, 1731, AGN, Casa de Moneda, vol. 417,
} 
había permitido que los oficiales estuvieran presentes en su pesado y ensaye. Tampoco se les había dado testimonio de las diligencias y peritajes correspondientes, como era el derecho de su parte y procedimiento judicial inexcusable. Por tanto, no constaba el cuerpo del delito, con lo cual los principales cargos de la acusación podrían ser tenidos como sin fundamento. En cuanto a la talla, dijeron que el tesorero había hallado la de 68 reales en observancia, que las leyes y ordenanzas al respecto admitían diversas interpretaciones y que en estas situaciones «se llama la costumbre la verdadera intérprete de la ley, cuya contravención fuese contravención de la misma ley». Incluso, sostenían que haber reducido la talla a 67 reales hubiera ocasionado pleitos y escándalos al entregar menos moneda a sus dueños ${ }^{72}$.

Méndez también solicitó que el escribano diera constancia de la caja donde se guardaban las unidades de peso, marcada con las armas reales y una placa alusiva a la visita realizada por el obispo Juan de Palafox en 1645. La caja efectivamente existía, con una tapa que representaba una flor de lis y dos manojos atados de flechas; dentro se halló un marco de bronce y cajitas con dinerales. El propósito del pedimento era demostrar que los antiguos dinerales estaban también ajustados a 68 reales, como así fue, pero Veytia notó inmediatamente que aunque las flechas podían pasar por armas reales (las había usado Isabel la Católica) no ocurría lo mismo con las flores de lis. Aunque ésta era una diligencia pedida por la defensa, le sirvió para adicionar un nuevo cargo a los ya existentes: suplantación dolosa de los dinerales ${ }^{73}$.

Por su lado, la alusión de un declarante llevó a Veytia a otra averiguación. En efecto, el capataz fundidor Joseph Fernández Pareja había dicho en su testimonio que frecuentemente las barras resultantes de la fundición de las cizallas (esto es, los recortes y fragmentos de plata) pertenecientes a Lamadriz salían faltas de ley. Esto era extraño, porque en principio se trataba del mismo metal empleado para acuñar las monedas. Lo propio, desde luego, era que hubiesen vuelto a afinarse, pero esto habría traído demoras y costos. El juez descubrió que el tesorero Medina había ordenado que se solucionara el problema mezclando las cizallas defectuosas de Lamadriz con las del marqués de Altamira y luego con las de Francisco de Valdivielso (en proporción de 1:20), que siempre salían correctas. Pareja, por su lado, dijo que se había puesto a averiguar el origen del defecto, pero cesó de hacerlo por temor a que le dieran un trabucazo. Para Veytia todo esto era prueba indirecta de la falta

exp. 5, folios 273-275 y Causas criminales contra falsificadores, 1735, AGN, Criminal, vol. 535, exp. 7, folios 165-173.

72 Márquez, 1735: 3-8.

73 AGN, Casa de Moneda, vol. 391, exp. 2, folio 177. 
de ley de las monedas, y no estuvo dispuesto a aceptar que simplemente el metal arribara sucio, mezclado con desechos que afectaran su pureza y ley. Por tanto, determinó agregar otro nuevo cargo ${ }^{74}$.

El banquero Lamadriz se presentó a declarar finalmente el 5 de junio de 1731, y se le interrogó con insistencia sobre las razones por las cuales las fundiciones de sus cizallas salían erradas. Sólo atinó a decir que era imposible que se les agregara más liga de la correspondiente, porque después de fundidas las barras volvían a reensayarse para comprobar que la ley fuese la correcta. En cuanto a la talla, sostuvo que había recibido la moneda de buena fe y que siempre se había hecho a 68 reales, y que si se hiciera en menos, los introductores se habrían quedado sin ganancia y no habría quien metiera platas a labrar. Este real suplementario, en su opinión, aunque pareciera redundar en favor de los mercaderes en realidad era en beneficio indirecto de todo el reino, común de la minería y particulares ${ }^{75}$. Su defensor, Francisco Manuel Chirlín, con más orden jurídico, procuró refutar los cargos y en particular argumentó que la talla y el beneficio adicional que recibían los mercaderes era "antiquísima e inmemorial costumbre, que es ley no escrita», y que la ausencia de caja de febles era «racionalísima costumbre legítimamente prescrita e introducida», y sobre el caso «milita el principio de derecho que prescribe ser el mejor intérprete de la ley la costumbre» ${ }^{76}$.

Los escarceos judiciales duraron varios meses hasta que se vieron bruscamente interrumpidos. En efecto, algo en el desarrollo del proceso debió generar inquietud en Madrid, porque el 2 de agosto de 1731 Patiño firmó una real orden para que todos los autos se enviaran a la Real Junta de Comercio y Moneda en la primera ocasión, concluidos y en estado de sentencia. Esta premura cayó mal a Veytia, quien comentó que era imposible que el fiscal examinara la ya voluminosa documentación antes de poder presentar su alegato. Dado que los navíos llamados «del azogue» estaban al partir, el juez mandó que se remitieran de inmediato los autos y que los acusados se presentaran ante la Real Junta para alegar sus derechos, por sí o mediante procuradores $^{77}$. Fue una medida que en la práctica dejó sin defensa a quienes no tenían suficientes recursos, porque el costo de contratar procuradores en Es-

74 Ibidem, folios 266-268.

75 Ibidem, vol. 362, exp. 6, folios 74-86.

76 Ibidem, folios 163-192. Puede apreciarse que en el trasfondo del argumento se hallaba la jurisprudencia sobre la aceptabilidad jurídica de la costumbre, que requería antigüedad, conocimiento del príncipe, racionalidad, no ser contraria al derecho natural ni al bien común, y haberse introducido a ciencia cierta. Bravo, 1989.

77 AGN, Casa de Moneda, vol. 391, exp. 2, folios 449-443. 
paña resultaba prohibitivo para la mayoría. Sólo Medina, Elizaga, Pérez Vello y los mercaderes lograron acceder a este recurso.

\section{La Causa y los alegatos en España}

La voz por la parte acusadora en la metrópoli la tomó el doctor Juan Ignacio de la Encina y la Carrera, fiscal de la Real Junta de Comercio y Moneda. El fiscal reiteró lo argumentado por Veytia y dedicó sus principales conocimientos a contradecir los argumentos de la defensa. Le inquietaba en particular el alegato de que no constaba la prueba del delito, y recurrió a un argumento de autoridad: el defecto alegado en las monedas estaba probado por la simple aserción del rey, que era la más concluyente y autorizada prueba, suficiente para la condena. En todo caso, el tribunal debía sentenciar según la verdad que resultare, simplemente y de plano, aunque hubiera algún defecto o falta jurídica en el proceso. Frente a la posible existencia de monedas falsificadas entre las que habían llegado con la flota y sido objeto de peritaje, tuvo un argumento original: no era creíble que un falsario se contentara con un defecto de dos a seis granos en la ley, como el observado, porque los delincuentes «arrestados ya a cometer tan enorme delito, jamás se contienen a tan moderada falta, como alimento corto a saciar el exceso de su ambición» ${ }^{78}$.

El fiscal se sentía en terreno más sólido en cuanto al incremento de la talla, en la que consideraba que los acusados estaban confesos. Aceptaba que la ley era muy obscura cuando establecía que en Indias se aplicarían tres reales para los oficiales, pero por otro lado se apoyaba en los autos de visita del virrey conde de Galve, donde se mencionaba que la moneda se labraba entonces a 67 reales. Los testimonios de algunos capataces, alegados por la parte contraria para sostener costumbre inmemorial, debían ser desechados, porque procuraban disculparse de un grave delito. En cuanto al principal descargo de los reos, de que habían informado debidamente al virrey Casafuerte y de lo cual se había derivado en 1724 la modificación de las ordenanzas, no era más que una confesión de delito continuado, que los colocaba en la categoría de reos que aconsejaban lo prohibido y pernicioso. Respecto a los posibles castigos, Encina señaló que los mercaderes, aunque no tan gravemente implicados, ameritaban una severa multa por haber sido cooperadores y beneficiados del fraude. Contra los oficiales, además de las penas propias de cada delito, correspondía el decomiso de los oficios ${ }^{79}$.

\footnotetext{
78 Encina y la Carrera, 1735: 3-20.

79 Ibidem: 27-41.
} 
Para comprender esta última propuesta debe atenderse a una decisión que estaba implícita en las nuevas ordenanzas de las casas de moneda indianas, pero que hasta entonces no se había llevado a cabo. En efecto, en obediencia a una real orden el 9 de marzo de 1733 finalmente se embargaron todos los oficios de la ceca mexicana, lo cual dejó a los antiguos oficiales sin ocupación ni ingresos. Desde luego, los beneficiarios podían reclamar la devolución de las sumas entregadas para la adquisición, porque el rey había vendido estos oficios y eran propiedad de los adquirentes. No eran cantidades menores; en el caso del tesorero, la familia Medina había pagado inicialmente 160.000 pesos por el puesto (más 140.000 a los anteriores poseedores), a lo cual debían agregarse gastos de confirmación, media anata y otras sumas devengadas para obtener prerrogativas tales como el nombramiento de un teniente, o el carácter hereditario y renunciable del oficio. La manera en que debía calcularse y pagarse este valor estaba abierta a diversas interpretaciones ${ }^{80}$. Era un tema muy sensible para la Real Hacienda, por lo cual la petición de decomiso realizada por el fiscal no parece para nada casual. También era un momento delicado, porque el cambio de administración de la ceca causó mucha agitación y la proliferación de toda clase de rumores. Incluso la influyente diputación de minería de Zacatecas había enviado al virrey una encendida representación, augurando inminentes desastres; y en círculos gubernamentales se llegó a hablar de las «cavilosidades» de los mercaderes y de los anteriores dueños de oficios ${ }^{81}$.

Por parte de la defensa, el capitán Francisco Antonio Pimentel de Sotomayor reiteró los descargos introducidos previamente y concentró sus argumentos en un aspecto que no era propiamente jurídico, pero que probablemente tocaría de cerca a los integrantes de la Real Junta de Comercio y Moneda. Esto es, después de discutir las contradicciones de las normas y alegar que en caso de duda «la ley decisiva es la inmemorial costumbre», dedicó lo más extenso de su alegato a mostrar que si se procediera a dar 65 reales por marco de plata a los banqueros resultaría en perjuicio del rey y del público, pues ninguno llevaría plata a amonedar ni aviaría a los mineros, con total ruina del comercio y del reino. Procuró también refutar lo dicho por el

80 A la larga, se acordó pagar a los dueños de oficio no en una sola exhibición, sino como si fuese un préstamo con réditos al 3\%. Estas sumas ascendieron a más de 30.000 pesos anuales, que siguieron devengándose hasta su final redención en 1777. Soria Murillo, 1994: 108.

81 Representaciones de la minería, diputados del comercio y corregidor de Zacatecas con los oficiales reales de aquellas cajas, 1733, AGN, Casa de Moneda, vol. 66, exp. 13, folios 295-328. Informe de lo ocurrido con los mineros de Zacatecas por la nueva reforma, AGN, Reales Cédulas Originales, vol. 55, exp. 6, 2 folios. 
fiscal Palacios acerca de los grandes aprovechamientos de los mercaderes, que habrían aumentado ilegalmente sus beneficios a un real y tres cuartillas por cada marco de plata. Según Pimentel esto no era cierto, porque de esta cantidad debían descontarse derechos de ensaye, mermas y gastos de fundición. De esta manera, si la ceca les devolviera 65 reales, solamente les quedaría una cuartilla de provecho por cada marco, lo cual no compensaba los impuestos, costos y riesgos. De creer a Pimentel, la amonedación más que un trato comercial era para los banqueros casi un servicio desinteresado al público y al rey, que además lograba por esta vía cuantiosos ingresos por vía de tasas directas e indirectas. Concluía, en fin, que dar 66 reales a los banqueros era un procedimiento «natural y genuino, apoyado de la razón, de la racional costumbre inmemorial, de la práctica pública, reconocida de los superiores ministros, no ignorada de su Majestad» ${ }^{82}$.

En efecto, si solamente se considerara la diferencia entre el precio legal del marco de plata antes de su amonedación, que era de 64 reales, y una hipotética retribución del mismo marco acuñado en 65 , el beneficio era escaso una vez descontados los gastos. La evidencia de otras cecas parecería confirmar lo alegado, porque en Sevilla los mercaderes solamente obtenían cuatro maravedíes por marco de plata (o sea, 4/34 de un real), y en Lima el provecho era tan reducido que los introductores solamente se mantenían gracias a que se les permitía quedarse con el feble ${ }^{83}$.

Esto no era del todo así en México. En efecto, debe distinguirse entre el valor legal del marco de plata y el precio de mercado al que adquirían los comerciantes este metal, en razón de la posición económica desigual de compradores y vendedores. Los mineros siempre estaban escasos del capital necesario para realizar obras de infraestructura, pagar operarios y comprar insumos, y no podían afrontar los gastos y dilaciones que implicaba trasladar el metal precioso a la capital virreinal para su acuñación en la única ceca autorizada. Casi todos dependían del avío de un comerciante que proporcionaba crédito para que le compraran todo lo necesario a los precios que arbitrariamente establecía, y quedaban obligados a pagar su adeudo con plata, con un descuento o «premio» respecto del valor legal. Con variaciones que dependían de diversos factores, este descuento era cercano a 8,1 reales por marco, esto es un $12,5 \%{ }^{84}$. Desde luego, debe también tenerse en cuenta el posterior pago de impuestos, como el quinto real (de hecho un diezmo), 1.5\% de ensaye y real de señoreaje, así como alcabalas del tránsito carretero, pero

\footnotetext{
82 Pimentel de Sotomayor, 1735: 27-39.

83 Donoso Anes, 2000: 218-219. Lazo García, 2006: 130-131.

84 Hoberman, 1991: 89-90.
} 
es evidente que era un trato muy lucrativo, aunque no exento de grandes riesgos, como muestra el caso de la quiebra del banco de plata de Lamadriz.

El 26 de junio de 1738 la Real Junta de Comercio y Moneda absolvió a los oficiales del primer cargo, de falta de ley de la moneda. En la acusación incidental de falta de ley en la cizalla, condenó a Medina en 2.000 pesos, al ensayador Rivas Angulo en otros 2.000 y al fundidor de cizallas Fernández de Pareja en 1.000 pesos. El mercader Lamadriz, de tan dudosa participación, fue declarado inocente.

En el segundo cargo, de falta de peso de la moneda, y en el tercero, de división del marco de plata en 68 reales, la Junta sentenció a Medina en 12.000 pesos, al balanzario Elizaga en 15.000, al guarda mayor Bustamante en 4.000, al escribano Picardo en 4.000, y al alcalde Méndez en 100 pesos. Respecto a los mercaderes de plata, condenaron a Valdivielso en 20.000, a Fagoaga en 15.000 y a Lamadriz en 10.000 pesos. Fueron absueltos el teniente de tesorero Pereda Palacio, ya difunto; los guarda mayores, marqués del Villar del Águila y Damián Pérez Vello; y los alcaldes Meléndez Bazán y Raymundo Campoy.

Del cargo cuarto, sobre no haberse entregado el feble al rey, ni haber arca para ese fin, y haber desviado el producido por la moneda, fueron todos declarados inocentes.

El tesorero Medina fue condenado en 1.000 pesos por el quinto cargo, de haber exigido derechos irregulares en el nombramiento de oficiales menores; pero fue tenido por no culpable del sexto, respecto de la falta de documentos del archivo.

En el cargo séptimo, los guardas mayores Pérez Vello y Bustamante fueron sentenciados en 250 y 500 pesos respectivamente, por no haber asistido al remache de troqueles y punzones; mientras el marqués del Villar fue absuelto.

En el cargo octavo, sobre mala estampa de las monedas, los jueces multaron al tesorero Medina, a los guarda mayores Pérez Vello y Bustamante, y al escribano Picardo en 400 pesos, repartidos por iguales partes.

Del último y noveno cargo, sobre no haber asistido a las reuniones de oficiales dispuestas por las ordenanzas, fueron absueltos los alcaldes Méndez, Meléndez y Campoy.

En cuanto a los mercaderes, se sentenció a Fagoaga (esto es, a sus herederos, porque había fallecido dos años antes) en 20.000 pesos, a Valdivielso en 15.000 pesos y a Lamadriz en 10.000 pesos, por los provechos irregularmente obtenidos.

Los condenados interpusieron una apelación, pero la sentencia se confirmó por auto de revista de 14 de mayo de 1739. Al mismo tiempo, se declaró por el rey que a Medina, Elizaga y Pérez Vello, pagadas las multas, se les alzasen 
las carcelerías y embargos, declarando que eran «buenos ministros servidores míos y dignos de mi real atención en todo lo correspondiente a sus grados y carácter». Y en una línea final muy interesante, se les dijo que como aún estaba pendiente el pago del valor de sus oficios, acudiesen sobre este punto a la Real Junta de Comercio y Moneda ${ }^{85}$.

Una vez deducidas las multas los encausados podían en principio recuperar los derechos embargados entre el 23 de junio de 1730 y el 9 de marzo de 1733, descontando lo que se les había dado en alimentos. En el caso del tesorero Medina, las cantidades secuestradas por concepto de derechos de amonedación habían sido (en números redondos) de 227.242 pesos, de los que se quitaron 129.439 pesos por gastos de braceaje, más 51.631 pesos por alimentos y 1.767 pesos que se pagaron por el salario de un teniente de tesorero. En total, le quedaron libres 44.405 pesos ${ }^{86}$.

No acabó aquí la odisea judicial de los acusados, porque toda causa que derivaba en sentencias condenatorias implicaba que los condenados pagaran las costas del proceso. Al final, la visita y los autos judiciales resultaron en 2.400 fojas de autos, 160 de memoriales y 7.628 de testimonios diversos en México, más otros 4.319 folios que se sumaron en España ${ }^{87}$. En 1744 seguían todavía actuaciones judiciales respecto de las cantidades que debían o no cobrarse a los oficiales ${ }^{88}$. Todo esto, desde luego, no abarcaba los gastos de la defensa. Solamente los referentes a actos efectuados en España eran de 30.102 pesos, que debían pagarse de mancomún ${ }^{89}$.

Un asunto lateral fue que entre los bienes embargados al tesorero había 20 negros esclavos, empleados como asalariados en las labores de fundición y acuñación. Medina pidió se le devolvieran, así como el sobrante de sus ingresos, descontados los gastos en alimento, vestimenta y atención religiosa. Se dispuso que así se hiciera, entregándolos en el estado y número en que

85 AGN, Casa de Moneda, vol. 62, exp. 10, folios 170-181. En el caso peruano, se dio sentencia absolutoria en contra de los oficiales encausados, con la declaración de que «habían procedido en sus empleos y oficios con el mayor celo, aplicación y desinterés a favor del real servicio, y como fieles, buenos y leales ministros»; Lazo García, 2006: 126-127.

86 AGN, Casa de Moneda, vol. 62, exp. 10, folios 212-239.

87 Testimonio de los autos de visita por lo que toca a Francisco de Fagoaga, 1754, ibidem, vol. 311, exp. 6, folios 145-194v.

88 Real cédula sobre moderación de costas de los autos de visita de esta Real Casa, 1739, ibidem, vol. 62, exp. 6, folios 16-40. Autos de la sentencia de vista y revista de la visita de la Casa de Moneda, 1744, ibidem, vol. 494, exp. 803, folios 1-3.

89 Cuenta presentada por Joseph Diego de Medina de los gastos en España en defensa de los cargos y causa, 1741, ibidem, vol. 62, exp. 9, folios 112-117. 
estaban al embargarlos, aunque resultó que varios habían muerto y otros estaban fugitivos. El remanente de los salarios fue de 6.584 pesos $^{90}$.

La sentencia permitió desatascar el viejo problema del adeudo entre Medina y los banqueros. Dado que se devolvían a los oficiales sus bienes, incluyendo los provechos embargados, se determinó que se cobraran de ellos, o bien que se tomaran de las sumas necesarias de los pagos que se harían a los anteriores propietarios de los oficios. Así, después de muchos años, los mercaderes lograron recuperar las sumas demandadas ${ }^{91}$.

\section{CONSIDERACIONES FINALES}

La historia del proceso judicial contra los oficiales de la Real Casa de Moneda de México y los banqueros de plata admite comentarios en diversos niveles. El más evidente e inmediato, desde luego, es el de la causa criminal sobre los delitos y abusos cometidos. En conjunto, más que un fraude deliberado, lo que aquí presenciamos se asemeja a una erosión paulatina de las normas, cuya aplicación con el tiempo y la tolerancia de las autoridades se había vuelto favorable a los intereses locales. La sentencia final, al dejar a salvo el honor de los principales acusados, parece señalar que así también lo consideró el tribunal ${ }^{92}$.

En este sentido, es muy reveladora la discusión subyacente detrás de los alegatos sobre la talla, los febles o la manera de los ensayes. En su defensa, tanto oficiales como banqueros apelaron a la «práctica y costumbre» pública, observada desde «tiempo inmemorial». Como se dijo en relación a la suma que recibían los banqueros por sus marcos de plata, era un procedimiento «natural y genuino, apoyado de la razón, de la racional costumbre inmemorial, de la práctica pública». Los defensores elevaron esta idea casi a términos de doctrina jurídica cuando sostuvieron que «se llama la costumbre la verdadera intérprete de la ley, cuya contravención fuese contravención de la misma ley». Incluso fueron más allá, al argumentar que «la ley decisiva es la inmemorial costumbre». Si esta aseveración hubiera sido aceptada, habría implicado acep-

90 Joseph Diego de Medina y Sarabia, sobre que se le paguen los jornales de los negros operarios, 1742, ibidem, vol. 447, exp. 6, folios 97-119.

91 AGN, Casa de Moneda, vol. 297, exp. 10, folios 212-239.

92 Es interesante señalar que la acusación nunca estableció los posibles paralelos con el caso del gran fraude ocurrido a mediados del siglo XVII en Potosí, en el virreinato peruano, aunque formalmente la acusación principal era por el mismo delito: rebaja clandestina del peso y la ley de la moneda por parte de un mercader de plata y el ensayador de la ceca, con participación o tolerancia de muchos otros reos. Sobre ese caso, véase Domínguez Ortiz, 1998. 
tar que la voluntad del supremo legislador estaba sujeta a la práctica establecida y aprobada por los súbditos. El fiscal Encina no dejó de notar y condenar esta vertiente de la defensa, cuando escribió que la costumbre no era otra cosa que el «asilo general, como si ésta pudiese introducirse por semejantes actos reprobados» ${ }^{93}$. Visto así, lo que está detrás de la causa era la contradicción ahora introducida entre la ley y la costumbre, cuando ambas habían coexistido previamente sin mayores conflictos.

O, también, entre un pasado defendido por unos y denostado por otros, y el intento de establecer una «nueva planta», no solamente en la ceca sino asimismo en las relaciones entre el rey y sus súbditos. En efecto, al mismo tiempo que corrían los escritos y autos ante los tribunales, tuvo lugar la reincorporación a la Corona de la administración de la ceca y la confiscación de los oficios concedidos a particulares, que mucha resistencia provocaron en la Nueva España. Fueron procesos simultáneos que no pueden separarse enteramente entre sí. Ciertamente, los notables paralelismos con el caso peruano no parecen para nada casuales. Más allá de la voluntad de combatir lo que llamaban abusos, que tampoco puede dejarse de lado, la principal preocupación de los ministros del rey en España fue introducir un nuevo orden en el comercio y amonedación de metales preciosos. El proceso judicial parece haber sido, sobre todo, una manera de romper con un pasado que ahora ya se tenía por inconveniente. Debería considerarse como un golpe de autoridad, como un recordatorio a los súbditos de allende los mares que nadie podía usurpar la real jurisdicción ni actuar con excesiva independencia.

\section{BIBLIOGRAFÍA}

Bertrand, Michel, Grandeur et misère de l'office: Les officiers de finances de Nouvelle-Espagne, XVIIe-XVIIIe siècles, Paris, Publications de la Sorbonne, 1999.

Bravo Lira, Bernardino, Derecho común y derecho propio en el Nuevo Mundo, Santiago de Chile, Jurídica, 1989.

Castro Gutiérrez, Felipe, Historia social de la Real Casa de Moneda de México, México, Universidad Nacional Autónoma de México, 2012.

Céspedes del Castillo, Guillermo, Las casas de moneda en los reinos de Indias. Vol. 1 Las cecas indianas en 1536-1825, Madrid, Museo Casa de Moneda, 1996.

93 Encina y la Carrera, 1735: 47. 
Domínguez Ortiz, Antonio, "La falsificación de moneda de plata peruana a mediados del siglo XVIII", Estudios americanistas, Madrid, Real Academia de la Historia, 1998: 149-166.

Donoso Anes, Rafael, "Mercado y mercaderes de oro y plata de Sevilla en la segunda mitad del siglo XVI", Antonio Miguel Bernal, Dinero, moneda y crédito en la monarquía hispánica, Madrid, Pons, 2000: 213-240.

Elhuyar, Fausto de, Indagaciones sobre la amonedación en Nueva España (ed. facs.), México, M. A. Porrúa, 1979.

Encina y la Carrera, Juan Ignacio de la, Por el real fisco. El Doct. D Juan Ignacio de la Encina y la Carrera, cavallero del orden de Santiago, del Consejo de su mag. y su fiscal en el Real de Hacienda y de la Junta de Comercio y Moneda, en la causa que pende en dicha Real Junta contra el thesorero, ensayador, y otros oficiales de la Casa de Moneda de México [s.p.i, 1735?], Biblioteca Británica, General Reference Collection (consultado en Google Books, 9 de octubre de 2014).

Encinas, Diego de, Cedulario indiano, 4 vols., ed. Alfonso García Gallo, Madrid, Instituto de Cultura Hispánica, 1945-1946.

Enciso Contreras, José, Testamentos y autos de bienes de difuntos de Zacatecas (1500-1604), Zacatecas, Tribunal Superior de Justicia del Estado de Zacatecas, 2000

González Gutiérrez, Pilar, Creación de casas de moneda en Nueva España, Alcalá, Universidad de Alcalá, 1997.

Goyas Mejía, Ramón, "Notas sobre la vida de Pedro Sánchez de Tagle”, Estudios de Historia Novohispana, 45 (México, 2011): 47-80.

Hoberman, Louisa Schell, Mexico's Merchant Elite, 1590-1660: Silver, State, and Society, Durham, Duke University, 1991.

Lazo García, Carlos, "Las zozobras de una ceca y una crisis económica en marcha", Obras escogidas de Carlos Lazo García. Vol. 1 Historia de la economía colonial, Lima, Fondo Editorial del Pedagógico San Marcos, 2006: 113-156.

Márquez, Francisco Xavier, Escripto en respuesta a los cargos hechos al capitán don Joseph Diego de Medina y Sarabia, tesorero propietario de la Real Casa de Moneda de esta corte, en la visita que de ella se ha hecho por el señor licenciado don Joseph Fernández Veitia Linaje..., México, Hogal, 1735? Colección Digital, Universidad Autónoma de Nuevo León, n. ${ }^{\circ}$ 1006045, http://www.dgb.uanl.mx/ (consultado el 9 de octubre de 2014).

Obregón, Gonzalo, La capilla de los Medina Picazo en la iglesia de Regina Coeli, México, Instituto Nacional de Antropología e Historia, 1971. 
Pérez Rosales, Laura, Familia, poder, riqueza y subversión: los Fagoaga novohispanos, 1730-1830, México, Universidad Iberoamericana/Real Sociedad Bascongada de los Amigos del País, 2003.

Pimentel de Sotomayor, Francisco Antonio, Por don Joseph Diego de Medina y Saravia, thesorero, y los demás oficiales mayores de la Real Casa de Moneda de México, y los mercaderes de plata de aquella ciudad. En los autos de pesquisa que contra ellos siguió don Joseph Fernández de Veytia, oidor de aquella Audiencia, y superintendente de dicha Casa..., Madrid, 1735, Colección Digital de la Universidad Autónoma de Nuevo León, n. ${ }^{\circ}$ 1006045, http://www.dgb.uanl.mx/ (consultado el 9 de octubre de 2014).

Pradeau, Alberto Francisco (ed.), Don Antonio de Mendoza y la Casa de Moneda de México en 1543. Documentos inéditos, México, Porrúa, 1953.

Recopilación de las leyes destos reynos, hecha por mandado de la Magestad Católica del Rey don Felipe Segundo nuestro señor, 5 vols. (ed. facs.), Valladolid, Lex Nova, 1982.

Recopilación de leyes de los reynos de las Indias, 4 vols., Madrid, Cultura Hispánica, 1973.

Sanchiz, Javier, "La familia Fagoaga. Apuntes genealógicos", Estudios de historia novohispana, 23 (México, 2000): 129-167.

Soria Murillo, Víctor Manuel, La Casa de Moneda de México bajo la administración borbónica, 1733-1821, México, Universidad Autónoma Metropolitana, 1994.

Tomás y Valiente, Francisco, La venta de oficios en Indias (1492-1606), Madrid, Instituto de Estudios Administrativos, 1972.

Valle Pavón, Guillermina del, "Bases del poder de los mercaderes de plata de la ciudad de México. Redes, control del Consulado y de la Casa de Moneda a fines del siglo XVII", Anuario de estudios americanos, 68/2 (Sevilla, 2011): 565-598.

Fecha de recepción: 12 de diciembre de 2014.

Fecha de aceptación: 20 de junio de 2015. 


\section{The force of the law and the haven of custom. Prosecution for fraud and abuses at Mexico's Royal Mint}

This article deals with fraud charges levied in 1729 against the officers of the Royal Mint of Mexico and major silver traders of New Spain, the proceedings for which lasted over ten years and led to a severe institutional crisis. The events studied provide an insight into institutional situations and industrial processes that are not usually mentioned in the documentation and a better understanding of the dominant role of merchants. They also allow comment on the meaning of legal procedure and the reforms promoted by the Crown in its relations with American vassals.

KEY WORDS: mints; customary law; monetary policies; Bourbon reforms. 